\title{
The Spatial and Mechanism Difference in the Export Evolution of Product Space in Global Countries
}

\author{
Shan $\mathrm{Li}^{1}$, Xun Li ${ }^{1} * \mathbb{D}$, Wei Lang ${ }^{1}\left(\mathbb{D}\right.$, Haohui Chen ${ }^{2} \mathbb{D}$ and Xiaoguang Huang ${ }^{3}$ \\ 1 School of Geography and Planning and China Regional Coordinated Development and Rural Construction \\ Institute, Sun Yat-Sen University, Guangzhou 510275, China; lishan8@mail2.sysu.edu.cn (S.L.); \\ langw3@mail.sysu.edu.cn (W.L.) \\ 2 Commonwealth Scientific and Industrial Research Organization, Faculty of Information Technology, \\ Monash University, Docklands VIC 3008, Australia; caronhaohui.chen@data61.csiro.au \\ 3 Department of Economics, Lingnan College, Sun Yat-Sen University, Guangzhou 510275, China; \\ huangxg3@mail2.sysu.edu.cn \\ * Correspondence: lixun@mail.sysu.edu.cn
}

Citation: Li, S.; Li, X.; Lang, W.; Chen, H.; Huang, $X$. The Spatial and Mechanism Difference in the Export Evolution of Product Space in Global Countries. Sustainability 2021, 13 2255. https://doi.org/10.3390/ su13042255

Academic Editor: Luca Mora

Received: 28 January 2021

Accepted: 16 February 2021

Published: 19 February 2021

Publisher's Note: MDPI stays neutral with regard to jurisdictional claims in published maps and institutional affiliations.

Copyright: (c) 2021 by the authors. Licensee MDPI, Basel, Switzerland. This article is an open access article distributed under the terms and conditions of the Creative Commons Attribution (CC BY) license (https:// creativecommons.org/licenses/by/ $4.0 /)$.

\begin{abstract}
This study focuses on investigating the changing export patterns, evolution characteristics, and influencing trade mechanisms of countries on a global scale. Based on comprehensive customs data, our study found that core location and export types, including machinery and chemical products, both play positive roles in promoting countries' economic development. Developed countries are more likely to be at the core of the product space and to export machinery and chemical products. Countries' R\&D investment can affect the export location and types regardless of their economy, while high education matters in developed countries, and FDI (Foreign Direct Investment) is critical in developing countries. It indicates that technological benefits created by human capital can promote the export economy. Nevertheless, developing countries are not able to release strong knowledge spillover effects through their education systems, and they are relying more on the introduction of foreign investment to bring new technology.
\end{abstract}

Keywords: product space; core location; export types; export evolution; developed and developing countries; trade influencing mechanism

\section{Introduction}

Along with the economic globalization, the trade relations among countries are getting closer, and export is playing an increasingly important role in the world economy. Export upgrading and evolution enhance the international competitiveness effectively, and it has become a popular research topic in recent years. Early mainstream studies on industrial evolution mostly focused on the economic perspective. Factor endowments and technological gap are be considered main factors to affect the countries' professional development pattern [1,2]. With the emergence of evolutionary economic geography since the 1990s, industrial evolution research has been extended with the geographic perspective [3-5]. Evolutionary economic geographers believe that the emerging industries are products of the branching process of existing related industries [6-9], and industries with cognitive proximity, organizational proximity, institutional proximity, social proximity, and geographic proximity on a macro-scale are more likely to drive each other [10-13]. Industrial upgrades include the development of new products and the improvement of original products with added value [14]. The spillover effect of this industrialization process is of significance to the sustainable development of the economy [15,16]. In recent years, "Product Space" [17] provides a new network perspective for geographers to study the product evolution, which has made breakthroughs in theoretical research and empirical methods of industrial upgrading. In the past, scholars of international trade networks mainly discussed the trade relations between economies under trade agreements [18]. 
Most of them take economies in international trade as the object and depict the international trade network by building a trade economic model. In their trade networks, nodes always represent countries and lines represent trade agreements. They focus on the impact of bilateral relations among trading countries, symmetry, policy tariffs $[19,20]$, social factors [21], and geographical distance [22] on global trade links, trade liberalization, international research, and development collaboration, and the stability of international trade networks [23,24]. Different from the above-mentioned trade network theory, the product space theory does not take enterprises or economies and countries as the research object but falls to the micro-product level, focusing on specific trade products in the trade market and the strategic position and competitiveness of the economy in global trade. Product space theory proposed outcomes-based proximity between products at a micro-scale to measure their correlation and evolution path quantitatively. Proximity is measured by the minimum probability of two advantaged products being exported together by the same country, which is a co-occurrence concept and means the higher the proximity of two products in the product space, the easier for one country to export one product to the other. The product space theory can study and visualize scientifically the proximities of products, global trade links, and export status of different countries in the product space $[17,25,26]$.

In the context of product space, industrial upgrade is essentially the process of a region developing export advantages on new-technology-dominated industry [27]. Most empirical studies visualized and studied export evolution under a snapshot state of the product space or under dynamic global product spaces. Countries' exports economy has changed, which leads to the reshaping of global trade pattern and the emergence of changing product space. Therefore, we believe countries' export evolution can be better analyzed and clarified in the dynamic product space. Product space theory has attracted extensive attention in geography $[12,28]$, which has pushed the industrial evolution under the path-dependent interpretation framework to a new stage [29].

Empirical studies found significant effects of exports on economic growth. Related research can be divided into two aspects. First, economic geography focuses on the relevance between the location of products in product space and the national economy. It is put forward that products located in the core area in the product space can move more easily than products in the periphery [17]. Countries with advantaged products located in different areas of the product space face different opportunities [30], suggesting that the position of a country in the product space matters. Many scholars have empirically studied this hypothesis $[30,31]$. However, there is no unified standard to measure how centrally connected a country is in the product space. To our knowledge, many used the indictors constructed by national economic attributes such as sophistication [32], ubiquity, and economic complexity [33] as alternative indices to measure a country's productivity.

A few studies start from the original proximity, which can clearly reflect the products' driven power such as topology core-periphery location in the product space to measure the productivity of regions [30,34]. Second, the mainstream economic theory also explores the impact of different industries on economic development. The early "resource curse" examines the relationship between primary products with advantages in a region and economic growth [35,36]. Specialization of different products matters for national trade [37]. Different products have different productivity, and countries with high-productivity products have better economic performance [32]. The measurement of product types is relatively uniform. Most are classified products according to Leamer classification coding by SITC (Standard International Trade Classification) $[17,37,38]$. Based on the above, we have reasons to believe that the country's core-periphery position and the specific export types in product space both have important impact on economic performance.

Product space is a new perspective to study the pattern and dynamic evolution of countries in the global trade pattern under the evolutionary economic geography in recent years. A review of the existing literature, mostly focused on product space research in a single country $[30,31,39,40]$, a few literatures selected individual developing countries and developed countries for descriptive comparison of their different positions in the global 
product space $[17,41]$. Few overall comparative studies have been conducted between developing and developed countries. Are there significant differences between developing and developed countries in the core-periphery position of the product space and exported types? What are the internal factors that influence the export dynamics of developing and developed countries? What policy recommendations should be adopted for countries with different levels of development? This will be the focus of this paper.

The main contributions of this paper are as follows: First, this study constructs the global product space network from 1995 to 2011 and propose a scientific method to measure a country's specific core-periphery location in product space. The new measurement, called core, is based on the relatively exogenous and topological indictor of product space itself. Second, the study finds that a country's export pattern, including core locations and specific export types, has an impact on the economic performance of all countries in the global trade. Third, the study makes an interesting empirical finding, that is, we find differences in the mechanisms affecting export core locations and export types in developed and developing countries through quantitative regression models.

The structure of this paper is organized as follows. The Section 2 introduces the data and method to construct the dynamic product space. The Section 3 proposes the new indictor to measure the core-periphery location in product space. The Section 4 examines the impact of the export pattern including export location and export types in product space on economic performance. The Section 5 depicts the characteristics of countries' exports evolution and reveals the internal mechanisms affecting national exports (see Figure 1). The last section presents the main conclusions.

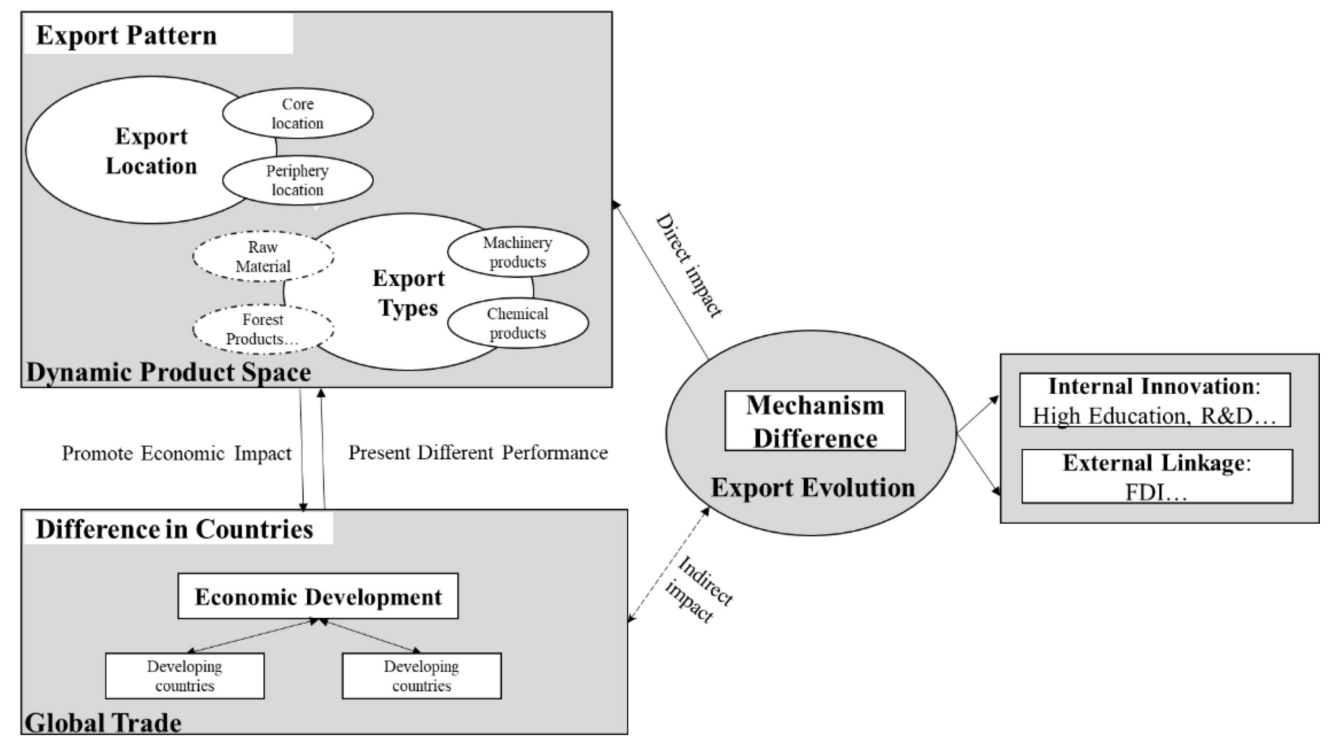

Figure 1. The research framework of this study.

\section{Materials and Methods}

\subsection{Data Resource}

The data in this paper include international customs data of the SITC4 four-digit code, the World Bank Data, and the Barro-Lee education data in the period 1995 to 2011. Among them, the international customs data before 2000 come from the "World Trade Flows: 1962-2000" data set [42], and the data from 2001 to 2011 come from the United Nations COMTRADE database. The attribute data including countries' population, foreign investment, and R\&D expenditures are from World Bank. Barro-Lee education data mainly includes educational attributes of countries around the world [43]. 


\subsection{The Construction of Dynamic Product Space}

The product space theory proposed by Hidalgo has become the main method to explore product evolution from the complex network perspective in the economic geography in recent years. The theory regards each specific product as a tree and all the trees make up the whole forest, it regards the enterprises as monkeys jumping in the forest, and the country is the aggregate of all the enterprises. The product space theory holds that the forest structure is heterogeneous, and the monkey can only jump a certain finite distance and cannot traverse the entire forest arbitrarily. The jumping process of monkeys reflects the transformation and upgrading process of industry. The more similar the demand for productive factors between products including natural resources, labor force, and human capital and so on, the higher the proximity and the easier the transfer of products.

Hidalgo used the minimum conditional probability of a country's simultaneous export of two products with comparative advantage to measure their result-oriented proximity. The greater the probability, the greater the proximity between the two products. A proximity greater than 0.55 means strong correlation of the two products. We use $\phi_{i, j}$ to represent proximity and use $R C A_{c, i}$ to represent the comparative advantage.

$$
\begin{gathered}
R C A_{c, i}=\frac{\frac{x(c, i)}{\sum_{i} x(c, i)}}{\frac{\sum_{c} x(c, i)}{\sum_{c, i} x(c, i)}} \\
\phi_{i, j}=\min \left\{P\left(R C A_{x_{i}} \mid R C A_{x_{j}}\right), P\left(R C A_{x_{j}} \mid R C A_{x_{i}}\right)\right\}
\end{gathered}
$$

At present, many scholars mostly study the industrial evolution in different years in the product space of a certain cross section. Only a few studies have studied it in the dynamic product space base [26]. However, as mentioned in the introduction above, changes in global trade linkages will lead to changes in the countries' overall export pattern. It is more realistic and scientific to study the export evolution under dynamic product space. Therefore, this paper explores the global industrial evolution process in the dynamic product space from 1995 to 2011 based on international customs data.

As shown in Figure 2, the product space was homogenized and there was only a laborintensive cluster of shoes and hats on the periphery, and the proximity of products located within the peripheral cluster and the core area was high in 1995 and 2000. The product space structure became relatively sparse and the products' links among countries weakened in 2000 compared with that in 1995, reflecting that the 1997 Asian financial crisis had a great impact on the global trade. The links of the global product space became increasingly tight in 2005 and 2011. The links of products are getting closer in the global product space in the next years. In 2005, the network began to polymerize, and it appeared to have preliminary and embryonic clusters. The products in the core area have increasing high proximities, and most of them are high valued in the global trade that are mainly composed of capitalintensive products, machinery, and chemicals. By 2011, the network had formed three clear industrial clusters: "Light Industrial Cluster", "Mechanical Equipment Cluster", and "Integrated Chemical Cluster". The proximities within the clusters are much closer, and high-value products are mainly distributed in the three clusters which are still dominated by capital-intensive products, machinery, and chemicals [44]. 


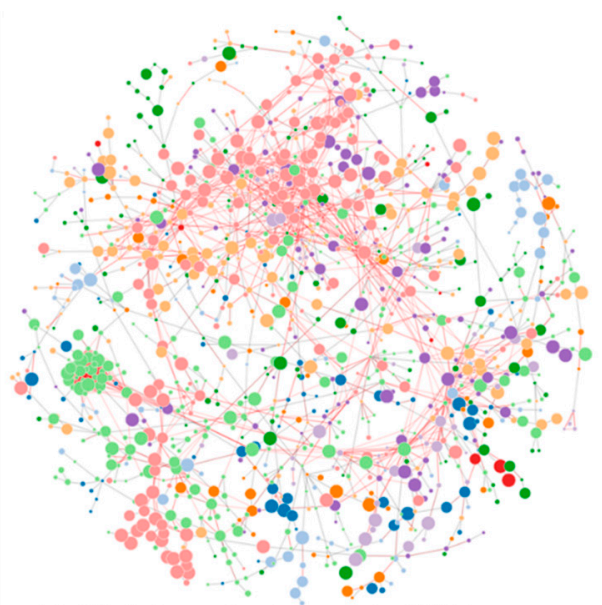

(a) Global product space in 1995

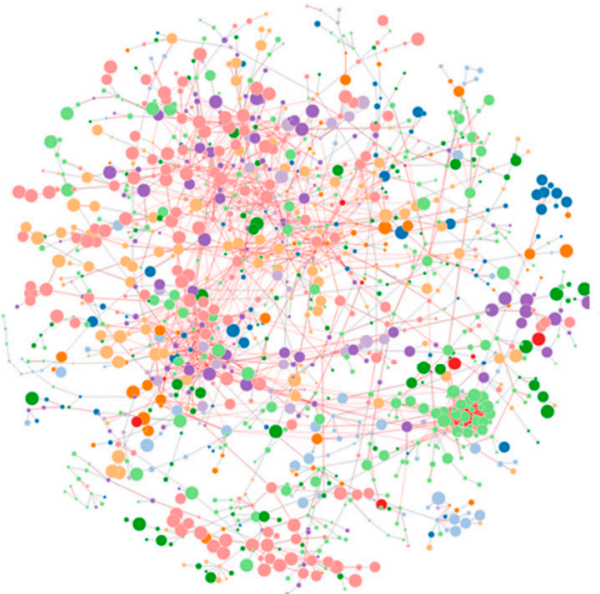

(c) Global product space in 2005

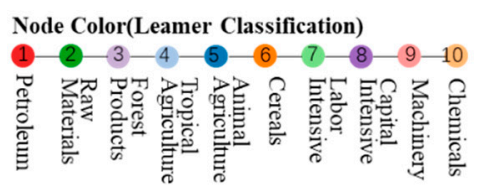

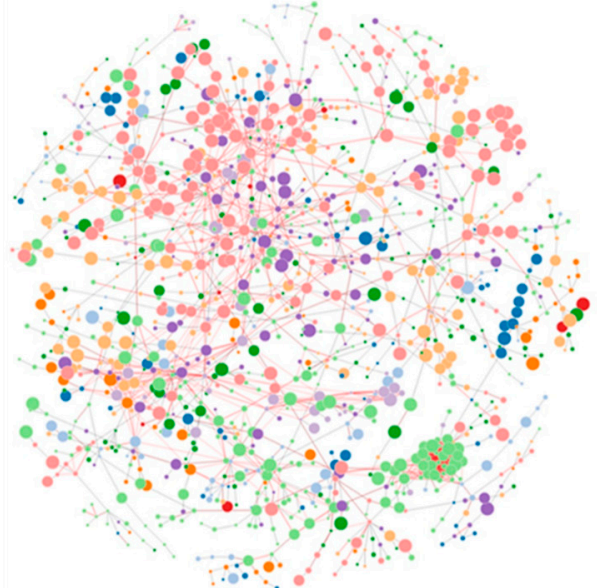

(b) Global product space in 2000

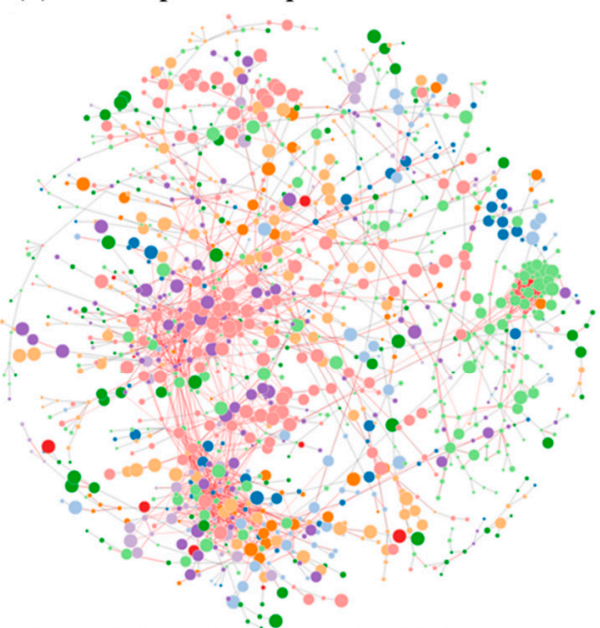

(d) Global product space in 2011

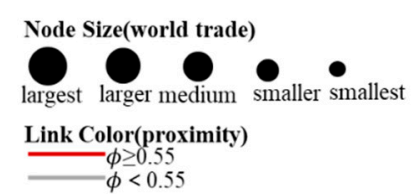

Figure 2. The dynamic global product space from 1995 to 2011. Notes: Each node represents a specific export product. The size of the node indicates the total trade value of the product in the world, and the color of the node represents the product type classified by Leamer classification. Links are color coded with their proximity value.

On the whole, the evolution of dynamic product space reflects the closer proximity between global products, showing the higher correlation within and between industries. It indicates that a country was no longer just exporting its existing specialized products and began to enrich the export baskets and change its traditional export pattern by obtaining abilities to produce related new products in international trade.

\section{New Measurement of an Indicator "Core" Based on Countries' Export Locations}

Economic geographers suggest that a country's initial product structure determines its future development, and specific export products have a direct impact on the development of the national economy [17,32]. Export core-periphery location and export types of countries in the product space are both important indicators that affect their development in the global trade pattern. Export types are easy to quantify. While quantifying the export itself, location is an issue worth discussing. We believe that the topological index of the product space itself based on products' proximities is a good exogenous indicator to measure a country's "core-periphery" location. At present, some scholars have qualita- 
tively described countries' spatial location in the product space by visualizing their export products' distribution in the product space, but they have not carried out unified scientific measurement.

As shown in Figure 3, we first visualize the export products of three developed countries (the United States, Japan, and Germany) and three developing countries (China, India, and Vietnam) in the global dynamic product space, and it shows obvious difference on export location and export types in developed and developing countries. Advantaged products of the United States, Japan, and Germany are mainly located in the core area of the network, and few are distributed in the periphery. Most of their advantaged products are machinery and chemicals. While the dominant products of China, India, and Vietnam are distributed in the periphery, and only a few gradually emerged in the core until 2011. Most of their advantaged products are labor intensive.

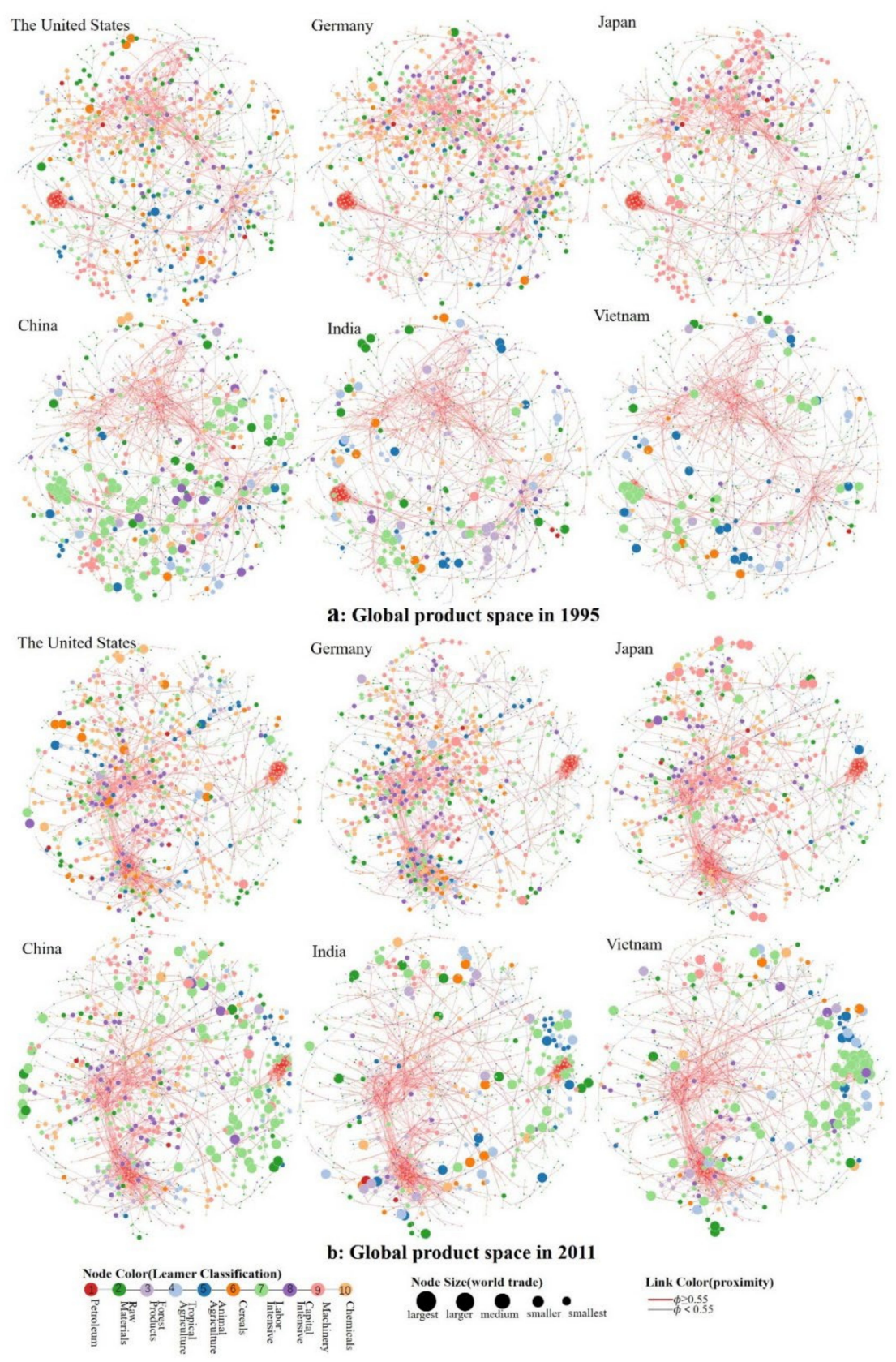

Figure 3. Location distribution of several developed and developing countries in the global product space in 1995-2011. 
Through the visualization of the distribution of several countries' positions respectively in the product space, we can address the exports of only a few countries but lack a quantitative measure to reveal the global export pattern. This research aims to quantify the role of countries' export locations and export types in the product space scientifically, and to discuss the internal interpretation mechanism. Firstly, this paper constructs the "core" indicator to calculate the position of a country in the product space and measure the overall core level of each country. Evolutionary economic geography believes that the proximity between advantaged products is the decisive factor in determining the evolution of industry. Referring to the principle that Neffke, Henning, Boschma and other scholars measured the closeness of each product with the overall proximity [30,34], we combine the algorithm of topological centrality of the complex social network commonly used in sociology as an indicator "Closeness $i$ " to measure a product's core-periphery location in product space.

The analysis regards the top 300 products with the biggest "Closeness" as a product set, $\mathbf{A}$. The "Core" of a country $j$ in product space, which is expressed by Core ${ }_{j}$, is determined by the number of its advantaged products belonging to A. As shown by the following formula. I is an indicative function, and the value is 1 when the product belongs to the core area product, otherwise it is 0 [45].

$$
\begin{aligned}
\text { Closeness }_{i} & =\frac{N-1}{\sum_{i=1, i \neq v}^{N} d\left(p_{i}, p_{v}\right)} \\
\text { Core }_{j} & =\sum I(i \in A)
\end{aligned}
$$

In order to demonstrate that export location and export types of a country affect its economic development, we construct regression models for analysis based on the 186 countries with complete data from the World Bank. The model takes the per capita gross domestic product PerGDP $j$ of each country as a dependent variable to measure its economic development, and takes export location Core ${ }_{j}$ and export types $T_{y p e_{j, i}}$ as independent variables to measure its specific export pattern. Type $j_{j, i}$ is calculated by the number of advantaged products in type $i$ based on Leamer classification in country $j$.

$$
\operatorname{PerGDP}_{j}=\alpha_{1} * \text { Core }_{j}+\alpha_{2} * \text { Type }_{j, i}+\alpha_{0}+\mu_{j}
$$

Results showed that the models were significant. Model (1) shows that a country's economy is positively related to its export "core". Model (2) shows that economy is also positively related to the technology intensive types "Machinery" and "Chemicals" products. Model (3) puts both the variables in the model and the model is still significant, and the result is consistent with the model having each variable separately. Please see Table 1.

On the whole, the core location and technology-intensive exports have a positive effect on promoting national economic development. In other words, developed countries tend to produce more products located in the core, such as machinery and chemicals, in the product space. It is consistent with the points that the core area of the product space is dominated by developed countries and developed countries export more productive products, which is proposed by Hidalgo and Hausmann et al. [17,32]. This indicates that the indicators we constructed are reasonable. 
Table 1. Regression model between export location and export types and economic development of countries.

\begin{tabular}{|c|c|c|c|}
\hline Variables & $\begin{array}{l}\text { Model (1) } \\
\text { PerGDP }\end{array}$ & $\begin{array}{l}\text { Model (2) } \\
\text { PerGDP }\end{array}$ & $\begin{array}{c}\text { Model (3) } \\
\text { PerGDP }\end{array}$ \\
\hline 1 Core & $\begin{array}{l}142.3 * * * \\
(23.36)\end{array}$ & & $\begin{array}{l}163.1^{* *} \\
(74.73)\end{array}$ \\
\hline 2 Type _Petroleum & & $\begin{array}{c}371.5 \\
(889.9)\end{array}$ & $\begin{array}{c}277.1 \\
(927.7)\end{array}$ \\
\hline $\begin{array}{l}2 \text { Type _Raw } \\
\text { materials }\end{array}$ & & 239.6 & 279.2 \\
\hline & & (206.3) & (203.5) \\
\hline $\begin{array}{l}2 \text { Type_Forest } \\
\text { products }\end{array}$ & & 139.2 & -93.87 \\
\hline & & $(219.2)$ & $(257.5)$ \\
\hline $\begin{array}{l}2 \text { Type _ Tropical } \\
\text { agriculture }\end{array}$ & & $-624.3^{* * *}$ & $-628.4^{* * *}$ \\
\hline & & (157.5) & (155.2) \\
\hline $\begin{array}{l}2 \text { Type _Animal } \\
\text { products }\end{array}$ & & 320.1 & 266.3 \\
\hline & & (210.8) & $(211.0)$ \\
\hline 2 Type_Cereals & & $\begin{array}{l}-127.5 \\
(217.9)\end{array}$ & $\begin{array}{l}-248.3 \\
(205.1)\end{array}$ \\
\hline $\begin{array}{l}2 \text { Type } \\
\text { Labour-intensive }\end{array}$ & & -69.40 & -35.70 \\
\hline & & (54.08) & (53.93) \\
\hline $\begin{array}{l}2 \text { Type } \\
\text { Capital-intensive }\end{array}$ & & -367.4 * & $-584.6^{* * *}$ \\
\hline & & (197.4) & (206.7) \\
\hline 2 Type _ Machinery & & $\begin{array}{l}292.8^{* * * *} \\
(112.2)\end{array}$ & $\begin{array}{l}198.3^{*} \\
(116.4)\end{array}$ \\
\hline 2 Type _Chemicals & & $\begin{array}{l}331.6^{* *} \\
(131.0)\end{array}$ & $\begin{array}{l}302.2^{* *} \\
(132.2)\end{array}$ \\
\hline Constant & $\begin{array}{l}8354^{* * * *} \\
(1631)\end{array}$ & $\begin{array}{l}9983^{* * * *} \\
(2879)\end{array}$ & $\begin{array}{c}11,389 * * * \\
(3005)\end{array}$ \\
\hline Observations & 186 & 186 & 186 \\
\hline R-squared & 0.148 & 0.414 & 0.425 \\
\hline
\end{tabular}

\section{Evolution of Product Space in Global Countries}

Based on the establishment of new indicators, this study will deeply analyze the global spatial distribution of dynamic export location and export types and figure out the internal influence mechanism of export evolution in the global trade pattern from 1995 to 2011 with detailed plant-level data. The World Bank divides countries into "highincome countries", "middle-high-income countries", "middle-low-income countries", and "low-income countries". This paper mainly examines the export pattern with different economic development. We consider that "high-income" represents developed countries, and "middle-high-income", "middle-low-income", and "low-income" countries are developing.

\subsection{Core Location Evolution of All Countries}

During the period 1995 to 2011, the countries with the largest increase in core were mainly high-income countries in Europe such as Poland, Portugal, and Spain, and a few developing countries in Asia such as China and Turkey, indicating that developing countries began to attach importance to producing core products and enhancing their export status (see Table 2). On the other hand, the countries with the largest decline in core were distributed in Europe and Africa, mainly including Switzerland, the United Kingdom, Norway, and Djibouti and Zimbabwe in Africa, but the difference is these European countries were still in a higher position in the world and the African countries had been at the bottom level on core. 
Table 2. The top 10 countries of "Core" and "Core" evolution during 1995 to 2011.

\begin{tabular}{|c|c|c|c|c|c|c|c|c|c|}
\hline \multirow[b]{2}{*}{ Rank } & \multicolumn{3}{|c|}{ Core in 1995} & \multicolumn{3}{|c|}{ Core in 2011} & \multicolumn{3}{|c|}{ Evolution from 1995 to 2011} \\
\hline & Country & Type & Core & Country & Type & Core & Country & Type & Core \\
\hline 1 & DEU & Developed & 228 & DEU & developed & 250 & POL & developed & 101 \\
\hline 2 & FRA & Developed & 187 & ITA & developed & 220 & TUR & developing & 95 \\
\hline 3 & AUT & Developed & 186 & AUT & developed & 216 & PRT & developed & 93 \\
\hline 4 & GBR & Developed & 179 & CZE & developed & 196 & LVA & developed & 78 \\
\hline 5 & CZE & Developed & 173 & FRA & developed & 196 & ESP & developed & 65 \\
\hline 6 & ITA & Developed & 169 & POL & developed & 196 & BGR & developing & 65 \\
\hline 7 & $\mathrm{CHE}$ & Developed & 164 & ESP & developed & 182 & $\mathrm{BIH}$ & developing & 60 \\
\hline 8 & USA & Developed & 157 & USA & developed & 169 & LTU & developed & 56 \\
\hline 9 & SWE & Developed & 151 & SVN & developed & 166 & ROU & developing & 53 \\
\hline 10 & DNK & Developed & 135 & SWE & developed & 158 & ITA & developed & 51 \\
\hline
\end{tabular}

\subsection{Evolution of Machinery and Chemical Exports of All Countries \\ 4.2.1. Evolution of Machinery Export in All Countries}

In 1995, most of the countries with the largest exports of machinery in the world were European, developed countries such as Germany, Italy, the Czech Republic, and developed Asian countries such as Japan. By 2011, the largest exporters of machinery were still these developed countries, but it is worth noting that China had become the only developing country in the top 10 mechanical exporters in the world (see Table 3). During the period 1995-2011, the countries with the largest increase in the machinery exports in the world were developed countries in Europe such as Poland, Estonia, and Italy and developing countries in Asia such as China, Turkey, and Thailand. The number of countries with an increase in mechanical exports accounted for $68 \%$ of all countries, which reflects the fact that most countries pay attention to the production of machinery. In particular, most European countries are in the forefront of the world on the exports of machinery and maintain a clear growth momentum.

Table 3. The top 10 countries for machinery exports and machinery evolution during 1995 to 2011.

\begin{tabular}{|c|c|c|c|c|c|c|c|c|c|}
\hline \multirow{2}{*}{ Rank } & \multicolumn{3}{|c|}{ Machinery in 1995} & \multicolumn{3}{|c|}{ Machinery in 2011} & \multicolumn{3}{|c|}{ Evolution from 1995 to 2011} \\
\hline & Country & Type & $\begin{array}{l}\text { Machinery } \\
\text { Products }\end{array}$ & Country & Type & $\begin{array}{l}\text { Machinery } \\
\text { Products }\end{array}$ & Country & Type & $\begin{array}{l}\text { Machinery } \\
\text { Products }\end{array}$ \\
\hline 1 & JPN & developed & 141 & DEU & developed & 150 & $\mathrm{CHN}$ & developing & 65 \\
\hline 2 & $\mathrm{DEU}$ & developed & 138 & JPN & developed & 133 & POL & developed & 39 \\
\hline 3 & $\mathrm{CHE}$ & developed & 107 & ITA & developed & 127 & EST & developed & 38 \\
\hline 4 & AUT & developed & 103 & $\mathrm{CHN}$ & developed & 110 & HRV & developing & 35 \\
\hline 5 & GBR & developed & 103 & CZE & developed & 106 & TUR & developing & 34 \\
\hline 6 & USA & developed & 103 & AUT & developed & 102 & ITA & developed & 33 \\
\hline 7 & ITA & developed & 94 & USA & developed & 102 & $\mathrm{CZE}$ & developed & 31 \\
\hline 8 & FRA & developed & 86 & $\mathrm{CHE}$ & developed & 99 & TUN & developing & 28 \\
\hline 9 & SWE & developed & 77 & FRA & developed & 98 & THA & developing & 27 \\
\hline 10 & CZE & developed & 75 & SWE & developed & 93 & $\mathrm{MAC}(\mathrm{CH})$ & developed & 27 \\
\hline
\end{tabular}

\subsubsection{Evolution of Chemicals Export in All Countries}

In the year 1995 and 2011, we find the top 10 countries for chemical exports in the world mainly belonged to developed countries, such as the United States in North America; Germany, the Netherlands, and France in Europe; and Japan in Asia. Only one developing country, India, was on the list. By 2011, the major chemical exports were still dominated by developed countries, but developing countries were beginning to appear more. Between 1995 and 2011, the changes in the quantity of chemical exports of countries were generally not large. High-income countries such as Japan, South Korea, and Singapore, in Asia were promoting chemical exports, and developing countries had gradually begun to increase their emphasis on the export of chemical products (see Table 4). 
Table 4. The top 10 countries of chemical exports and chemical evolution.

\begin{tabular}{|c|c|c|c|c|c|c|c|c|c|}
\hline \multirow{2}{*}{ Rank } & \multicolumn{3}{|c|}{ Chemical in 1995} & \multicolumn{3}{|c|}{ Chemical in 2011} & \multicolumn{3}{|c|}{ Evolution from 1995 to 2011} \\
\hline & Country & Type & $\begin{array}{l}\text { Chemical } \\
\text { Products }\end{array}$ & Country & Type & $\begin{array}{l}\text { Chemical } \\
\text { Products }\end{array}$ & Country & Type & $\begin{array}{l}\text { Chemical } \\
\text { Products }\end{array}$ \\
\hline 1 & DEU & developed & 133 & USA & developed & 134 & ESP & developed & 35 \\
\hline 2 & USA & developed & 116 & DEU & developed & 120 & JPN & developed & 34 \\
\hline 3 & NLD & developed & 107 & NLD & developed & 107 & THA & developing & 25 \\
\hline 4 & FRA & developed & 101 & FRA & developed & 99 & ITA & developing & 21 \\
\hline 5 & GBR & developed & 99 & GBR & developed & 86 & KOR & developing & 20 \\
\hline 6 & CHE & developed & 81 & ESP & developed & 85 & CYP & developed & 20 \\
\hline 7 & ISR & developed & 65 & JPN & developed & 72 & $\mathrm{CHN}$ & developing & 19 \\
\hline 8 & CZE & developed & 57 & ITA & developed & 71 & EGY & developing & 18 \\
\hline 9 & IND & developing & 56 & IND & developing & 71 & USA & developing & 18 \\
\hline 10 & ITA & developed & 50 & $\mathrm{CHN}$ & developing & 68 & SGP & developed & 17 \\
\hline
\end{tabular}

Figure 4 shows the evolution of core, machinery exports, and chemical exports of all countries from the year 1995 to 2011 in global trade. In the map visualization, a very few countries or islands that do not appear in the global customs data are regarded as not carrying out export trade, and the corresponding index is regarded as zero. We can see that the developed countries in Europe and America are at the forefront of the core location, machinery, and chemicals export. Although developing countries in Asia and Africa have no leading position in the export core location and export types, they show a positive upward trend. A small number of African, undeveloped countries have always been at the bottom level in these aspects, and their evolution process is slow.

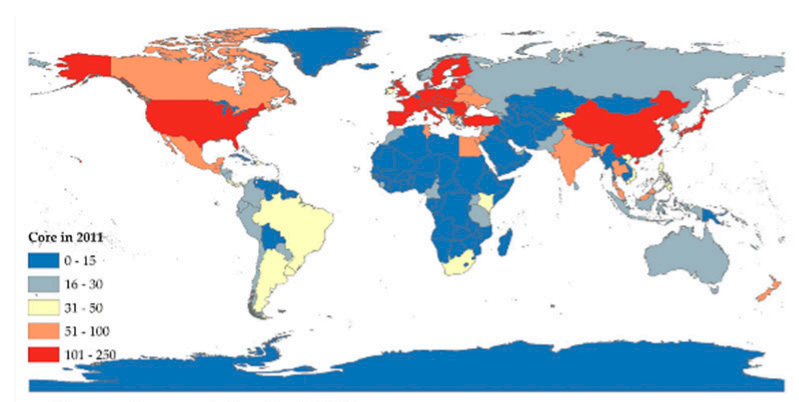

a-Core of countries in 2011

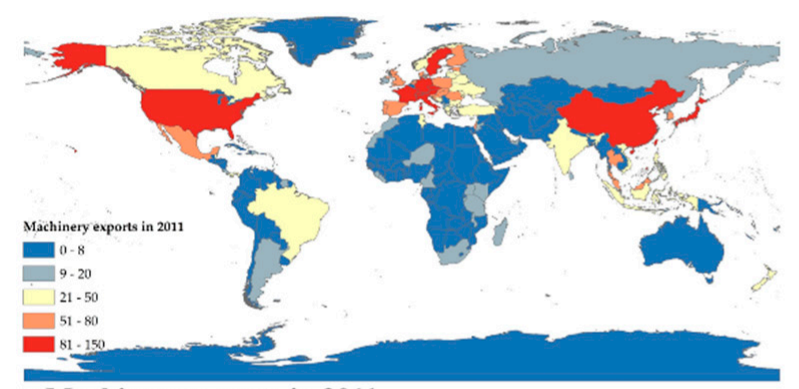

c-Machinery exports in 2011

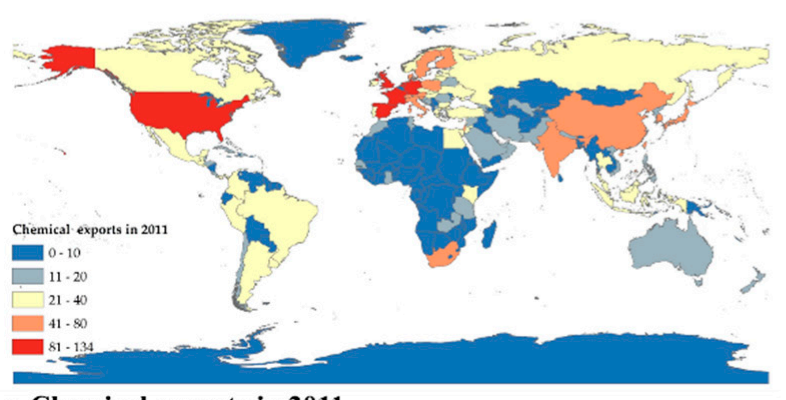

e-Chemical exports in 2011

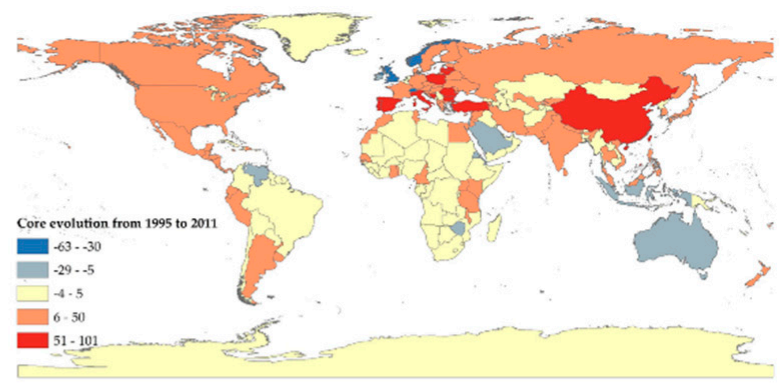

b-Evolution of core in countries from 1995 to 2011

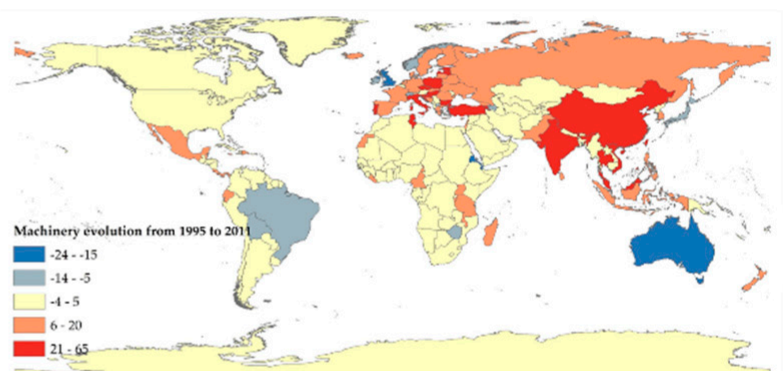

d-Evolution of machinery exports in countries from 1995 to 2011

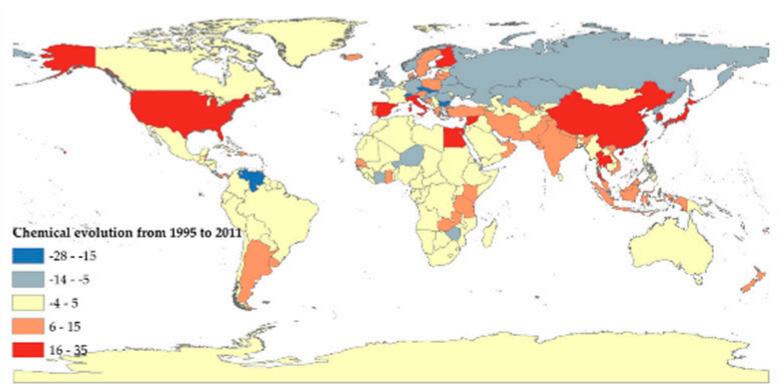

f-Evolution of chemical exports in countries from 1995 to 2011

Figure 4. The spatial distribution of core and export types of different countries in the world. 
We can see that there are significant differences in the performance and evolution on the core location and export types of countries with different levels of economic development. What is the internal mechanism that affects countries' export core location and export types? What are the main factors led to different processes of export evolution? Are there individual differences in the influence mechanism among countries with different development levels? We will discuss these in depth in the following.

\section{Mechanism Difference of Export Evolution in Developed and Developing Countries}

A country's specific export location and export types under the product space essentially reflect the country's export competitiveness. The scholars generally believe that technological progress is the main driving force for the industrial evolution by developing new production process and improving production efficiency and then promoting the development of original industries to the related industries. The main production factors affecting technological progress include labor force, human capital, and foreign investment. First, the scale of the labor pool promotes technical exchanges to promote knowledge spillovers and spawn new technologies. Secondly, human capital, as a key force in technological progress, can enhance the effect of "learn by do" and knowledge spillovers and promote the introduction and absorption of technology [46]. Human capital is mainly reflected in the two aspects of education and R\&D innovation. Many scholars believe that educated workers learn faster at work [47], specifically, higher education can better promote the economy and exports [34]. R\&D activities generate the ability to accumulate and create knowledge, promote production processes, and technology innovation and drive the radical evolution of the industry $[48,49]$. The experience of economic development in developed countries proves that increasing R\&D investment can promote technological progress. The reason why some underdeveloped countries have long been locked in the backward level is that the investment in the knowledge production sector is not enough and the rate of technological progress is too low [50]. In addition, the new growth theory emphasizes the effect of technology diffusion in international trade, and foreign investment as a potential transportation for international technology diffusion [51], can promote technological progress in the host country through the knowledge transfer by multinational companies $[52,53]$.

Based on the above theory, we used global customs data and other socioeconomic data of countries to construct regression models that will reveal the internal mechanism affecting the export location and export types under the product space. Because the Barro-Lee educational attribute data are sequence data with an interval of five years, all the research data we used are from 1995, 2000, 2005, and 2010. Due to the availability of all data, the study sample includes a total of 93 countries. The dependent variables of the models are the export location, Core ${ }_{j t}$, and export types, $T y p e_{j t}$, including machinery products and chemical products. The main explanatory variables include the internal innovation represented by human capital, the extra-regional linkage represented by foreign investment, and the total labor pool represented by population. Human capital includes education level and research and development capability, in which education level, EDU, is measured by the completion rate of high education [43], and research and development capability, $\mathrm{RD}$, is measured by the proportion of its expenditure to GDP. Foreign investment, FDI, is measured by the amount of foreign direct investment. The labor force, POP, is measured by total population. In addition, considering the country's Core and exports of specific types are related to its total export basket, we take export diversity, Div, which is measured by the number of all advantaged products exported by a country as the control variable of the models [54]. A Hausman test on our panel models shows that most regression models have passed the test, which indicates they are suitable for fixed-effect models, while several models on machinery and chemical exports have not passed the test, indicating that they are suitable for random models. By analyzing the significance and coefficient of variables under the model of fixed effect and random effect, it is found that the model is robust.

Core $_{j t}=\gamma_{1} * R D_{j t}+\gamma_{2} * E D U_{j t}+\gamma_{3} * \ln (F D I)_{j t}+\gamma_{4} * \ln (P O P)_{j t}+\gamma_{5} * \ln (\text { Div })_{j t}+\gamma_{c}+\eta_{t}+\varepsilon_{j t}$ 


$$
\text { Type }_{j t}=\theta_{1} * R D_{j t}+\theta_{2} * E D U_{j t}+\theta_{3} * \ln (F D I)_{j t}+\theta_{4} * \ln (P O P)_{j t}+\theta_{5} * \ln (D i v)_{j t}+\gamma_{c}+\eta_{t}+\sigma_{j t}
$$

\subsection{Mechanism of Export Evolution in All Countries}

Table 5 shows that the models (1-6) under the whole sample are significant. The results reflect that a country's Core in the product space is affected by both the level of education, EDU, in human capital and the factors of foreign direct investment, FDI (models 1 and 2); the export type of machinery is only subject to the variables of human capital including EDU and RD (models 3 and 4), and chemical exports maybe are only affected by RD (models 5 and 6).

Table 5. The regression results of driven force on core and export type evolution in all countries.

\begin{tabular}{|c|c|c|c|c|c|c|}
\hline & Model(1) & Model(2) & Model(3) & Model(4) & Model(5) & Model(6) \\
\hline & Core & Core & Machinery & Machinery & Chemical & Chemical \\
\hline & FE & RE & FE & RE & FE & RE \\
\hline $\mathrm{RD}$ & $\begin{array}{c}5.426 \\
(5.029)\end{array}$ & $\begin{array}{c}11.010 * * \\
(5.035)\end{array}$ & $\begin{array}{l}9.542 * * \\
(3.823)\end{array}$ & $\begin{array}{c}13.044^{* * *} \\
(3.109)\end{array}$ & $\begin{array}{l}2.559 \\
(2.532)\end{array}$ & $\begin{array}{c}7.837^{* * *} \\
(1.979)\end{array}$ \\
\hline EDU & $\begin{array}{l}1.202 * * \\
(0.525)\end{array}$ & $\begin{array}{c}0.624 \\
(0.386)\end{array}$ & $\begin{array}{c}0.574^{* * * *} \\
(0.213)\end{array}$ & $\begin{array}{c}0.316 \\
(0.202)\end{array}$ & $\begin{array}{c}0.143 \\
(0.148)\end{array}$ & $\begin{array}{c}0.150 \\
(0.153)\end{array}$ \\
\hline LnFDI & $\begin{array}{l}2.633 * \\
(1.410)\end{array}$ & $\begin{array}{l}2.784^{* *} \\
(1.157)\end{array}$ & $\begin{array}{c}0.920 \\
(0.642)\end{array}$ & $\begin{array}{l}1.165 \\
(0.714)\end{array}$ & $\begin{array}{c}0.126 \\
(0.605)\end{array}$ & $\begin{array}{c}0.606 \\
(0.482)\end{array}$ \\
\hline LnPOP & $\begin{array}{c}-5.302 \\
(17.815)\end{array}$ & $\begin{array}{l}-2.022 \\
(2.509)\end{array}$ & $\begin{array}{l}-0.094 \\
(8.891)\end{array}$ & $\begin{array}{c}1.274 \\
(1.551)\end{array}$ & $\begin{array}{c}16.532 * * \\
(7.036)\end{array}$ & $\begin{array}{c}3.573^{* * *} \\
(1.245)\end{array}$ \\
\hline LnDiv & $\begin{array}{c}74.107^{* * *} \\
(10.140)\end{array}$ & $\begin{array}{c}50.474^{* * *} \\
(9.151)\end{array}$ & $\begin{array}{c}28.628 * * * \\
(5.485)\end{array}$ & $\begin{array}{c}21.389 * * * \\
(4.147)\end{array}$ & $\begin{array}{c}23.205^{* * *} \\
(3.746)\end{array}$ & $\begin{array}{c}17.475^{* * *} \\
(3.093)\end{array}$ \\
\hline Constant & $\begin{array}{l}-307.940 \\
(279.211)\end{array}$ & $\begin{array}{c}-240.069 * * * \\
(47.146)\end{array}$ & $\begin{array}{l}-145.850 \\
(144.982)\end{array}$ & $\begin{array}{c}-137.167^{* * * *} \\
(24.546)\end{array}$ & $\begin{array}{c}-368.231^{* * * *} \\
(109.621)\end{array}$ & $\begin{array}{c}-140.359 \text { *** } \\
(23.669)\end{array}$ \\
\hline $\begin{array}{l}\text { Individual } \\
\text { effect }\end{array}$ & control & control & control & control & control & control \\
\hline $\begin{array}{l}\text { Observations } \\
\text { R-squared }\end{array}$ & $\begin{array}{c}246 \\
0.519\end{array}$ & 246 & $\begin{array}{c}246 \\
0.420\end{array}$ & 246 & $\begin{array}{c}246 \\
0.350\end{array}$ & 246 \\
\hline $\begin{array}{c}\text { Number of } \\
\text { countries }\end{array}$ & 93 & 93 & 93 & 93 & 93 & 93 \\
\hline $\begin{array}{l}\text { Hausman test: } \\
\text { chi2(6) }\end{array}$ & \multicolumn{2}{|c|}{$\begin{array}{c}21.32 \\
0.0016\end{array}$} & \multicolumn{2}{|c|}{$\begin{array}{c}10.95 \\
0.0898\end{array}$} & \multicolumn{2}{|c|}{$\begin{array}{c}25.68 \\
0.0003\end{array}$} \\
\hline
\end{tabular}

Notes: ${ }^{* * *} p<0.01,{ }^{* *} p<0.05,{ }^{*} p<0.1$.

\subsection{Mechanism of Export Evolution in Developed and Developing Countries}

Table 6 shows that the intrinsic factors affecting the export Core in developed and developing countries vary greatly in developed countries according to models ( 7 and 8) and models (13 and 14). Models ( 7 and 8 ) show the level of high education, EDU, mainly plays a positive role in improving the export Core of developed countries, while models (13 and 14) show foreign direct investment, FDI, can promote the export Core of developing countries. This means the internal innovation can really work in developed countries but not in developing countries, while the extra-regional linkage, which brings technology spillovers and related connections outside is the main reason for promoting evolutionary progress in developing countries.

In terms of education, this is consistent with the academic conclusions about the impact of education on the economics of different countries. Studies have shown that the industrialization process in most developed countries benefits from educational achievements [55-59], while the Philippines and the Middle East and other underdeveloped countries enjoy educational advantages but no economic advantage $[27,55]$. High education in developed countries can be well matched with high-tech jobs in the market, and knowledge spillovers can be used to promote technological innovation. However, in the 
developing countries, the number of talents with high education is in oversupply and the quality is still lacking, resulting in low effective return on education.

In terms of foreign direct invest, it is relatively more important in developing countries. FDI is conducive to developing countries to obtain advanced foreign technology at low cost and promote their technological progress and economic development [44,57], which is one of the most effective ways to narrow the gap between developed countries and developing countries and achieve a catch-up strategy.

Table 6. The regression results of driven force on core location and export type evolution in developed countries and developing countries, respectively.

\begin{tabular}{|c|c|c|c|c|c|c|c|c|c|c|c|c|}
\hline & \multicolumn{6}{|c|}{ Developed Countries } & \multicolumn{6}{|c|}{ Developing Countries } \\
\hline & $\begin{array}{l}\text { Model } \\
\text { (7) }\end{array}$ & $\begin{array}{c}\text { Model } \\
\text { (8) }\end{array}$ & $\begin{array}{l}\text { Model } \\
\text { (9) }\end{array}$ & $\begin{array}{l}\text { Model } \\
\text { (10) }\end{array}$ & $\begin{array}{l}\text { Model } \\
\text { (11) }\end{array}$ & $\begin{array}{l}\text { Model } \\
\text { (12) }\end{array}$ & $\begin{array}{l}\text { Model } \\
\text { (13) }\end{array}$ & $\begin{array}{l}\text { Model } \\
\text { (14) }\end{array}$ & $\begin{array}{l}\text { Model } \\
\text { (15) }\end{array}$ & $\begin{array}{c}\text { Model } \\
\text { (16) }\end{array}$ & $\begin{array}{l}\text { Model } \\
\text { (17) }\end{array}$ & $\begin{array}{l}\text { Model } \\
\text { (18) }\end{array}$ \\
\hline & Core & Core & Machinery & Machinery & Chemical & Chemical & Core & Core & Machinery & Machinery & Chemical & Chemical \\
\hline & FE & RE & FE & RE & FE & RE & FE & RE & FE & RE & FE & RE \\
\hline RD & $\begin{array}{c}7.046 \\
(6.047)\end{array}$ & $\begin{array}{c}6.787 \\
(5.711)\end{array}$ & $\begin{array}{l}7.281^{* *} \\
(2.776)\end{array}$ & $\begin{array}{c}8.671^{* * *} \\
(2.335)\end{array}$ & $\begin{array}{c}1.103 \\
(3.346)\end{array}$ & $\begin{array}{c}3.955 \\
(2.407)\end{array}$ & $\begin{array}{c}7.643 \\
(7.344)\end{array}$ & $\begin{array}{c}18.214 \\
* * * \\
(5.178)\end{array}$ & $\begin{array}{c}21.551 * * \\
(9.511)\end{array}$ & $\begin{array}{c}20.061^{* *} \\
(8.195)\end{array}$ & $\begin{array}{c}3.104 \\
(3.158)\end{array}$ & $\begin{array}{c}8.111^{* * *} \\
(2.036)\end{array}$ \\
\hline EDU & $\begin{array}{l}1.591 * * \\
(0.746)\end{array}$ & $\begin{array}{c}0.324 \\
(0.520)\end{array}$ & $\begin{array}{c}0.800^{* * *} \\
(0.276)\end{array}$ & $\begin{array}{c}0.331 \\
(0.269)\end{array}$ & $\begin{array}{c}0.015 \\
(0.234)\end{array}$ & $\begin{array}{c}0.082 \\
(430.209)\end{array}$ & $\begin{array}{c}0.445 \\
(0.629)\end{array}$ & $\begin{array}{c}0.128 \\
(0.446)\end{array}$ & $\begin{array}{c}0.439 \\
(0.364)\end{array}$ & $\begin{array}{c}0.040 \\
(0.244)\end{array}$ & $\begin{array}{c}0.249 \\
(0.184)\end{array}$ & $\begin{array}{c}0.164 \\
(0.138)\end{array}$ \\
\hline LnFDI & $\begin{array}{c}1.604 \\
(1.804)\end{array}$ & $\begin{array}{c}1.429 \\
(1.331)\end{array}$ & $\begin{array}{c}0.539 \\
(0.794)\end{array}$ & $\begin{array}{c}0.405 \\
(0.849)\end{array}$ & $\begin{array}{c}0.695 \\
(0.731)\end{array}$ & $\begin{array}{c}0.908 \\
(0.698)\end{array}$ & $\begin{array}{c}4.950^{* * *} \\
(1.824)\end{array}$ & $\begin{array}{c}5.042^{* * *} \\
(1.640)\end{array}$ & $\begin{array}{l}1.945^{*} \\
(1.037)\end{array}$ & $\begin{array}{c}2.539 * * * \\
(0.835)\end{array}$ & $\begin{array}{c}-1.075^{*} \\
(0.625)\end{array}$ & $\begin{array}{l}-0.055 \\
(0.566)\end{array}$ \\
\hline LnPOP & $\begin{array}{l}-39.458 \\
(31.845)\end{array}$ & $\begin{array}{c}3.097 \\
(3.855)\end{array}$ & $\begin{array}{l}-16.219 \\
(14.983)\end{array}$ & $\begin{array}{l}5.342 * \\
(2.892)\end{array}$ & $\begin{array}{l}25.760 * \\
(14.164)\end{array}$ & $\begin{array}{c}7.054^{* * *} \\
(2.447)\end{array}$ & $\begin{array}{c}15.836 \\
(21.530)\end{array}$ & $\begin{array}{c}-5.154 * \\
(2.809)\end{array}$ & $\begin{array}{c}0.867 \\
(12.653)\end{array}$ & $\begin{array}{l}-1.372 \\
(1.190)\end{array}$ & $\begin{array}{c}21.968^{* *} \\
(9.425)\end{array}$ & $\begin{array}{c}4.231^{* * *} \\
(1.342)\end{array}$ \\
\hline LnDiv & $\begin{array}{c}75.792 \\
* * *\end{array}$ & $\begin{array}{c}69.160 \\
* * *\end{array}$ & $\begin{array}{c}27.822 \\
* * *\end{array}$ & $\begin{array}{c}29.191 \\
* * * \\
(6679)\end{array}$ & $\begin{array}{c}31.840 \\
* * *\end{array}$ & $\begin{array}{c}22.552 \\
* * *\end{array}$ & $\begin{array}{c}61.494 \\
* * *\end{array}$ & $\begin{array}{c}25.205 \\
* * *\end{array}$ & $\begin{array}{c}23.648 \\
* * * \\
(6671)\end{array}$ & $9.992^{* * *}$ & $\begin{array}{c}16.086 \\
* * *\end{array}$ & 10.154 \\
\hline Constant & $\begin{array}{c}(18.028) \\
252.765 \\
(533.861)\end{array}$ & $\begin{array}{c}(13.725) \\
-375.486 \\
* * * \\
(68.533)\end{array}$ & $\begin{array}{c}(9.535) \\
131.288 \\
(257.285)\end{array}$ & $\begin{array}{c}(6.679) \\
-216.274 \\
* * * \\
(33.792)\end{array}$ & $\begin{array}{c}(7.721) \\
-558.571 \\
* * \\
(248.302)\end{array}$ & $\begin{array}{c}(4.617) \\
-217.307 \\
* * * \\
(37.440)\end{array}$ & $\begin{array}{c}(11.664) \\
-655.052 \\
* \\
(347.715)\end{array}$ & $\begin{array}{c}(7.889) \\
-115.593 \\
* * * \\
(33.354)\end{array}$ & $\begin{array}{c}(6.671) \\
-168.011 \\
(208.711)\end{array}$ & $\begin{array}{c}(3.400) \\
-69.699 \\
* * * \\
(21.669)\end{array}$ & $\begin{array}{c}(4.924) \\
-416.611 \\
* * * \\
(145.340)\end{array}$ & $\begin{array}{c}(2.707) \\
-107.358 \\
* * * \\
(22.908)\end{array}$ \\
\hline $\begin{array}{l}\text { Individual } \\
\text { effect }\end{array}$ & control & control & control & control & control & control & control & control & control & control & control & control \\
\hline Observations & 128 & 128 & 128 & 128 & 128 & 128 & 118 & 118 & 118 & 118 & 118 & 118 \\
\hline $\begin{array}{c}\text { R- } \\
\text { squared }\end{array}$ & 0.500 & & 0.398 & & 0.394 & & 0.624 & & 0.551 & & 0.389 & \\
\hline $\begin{array}{l}\text { Number } \\
\text { of coun- } \\
\text { tries }\end{array}$ & 40 & 40 & 40 & 40 & 40 & 40 & 53 & 53 & 53 & 53 & 53 & 53 \\
\hline $\begin{array}{c}\text { Hausman } \\
\text { test } \\
\text { chi2(6) }\end{array}$ & \multicolumn{2}{|c|}{23} & \multicolumn{2}{|c|}{9.6} & \multicolumn{2}{|c|}{9.29} & \multicolumn{2}{|c|}{22.41} & \multirow{2}{*}{\multicolumn{2}{|c|}{0.1672}} & \multicolumn{2}{|c|}{10.85} \\
\hline Prob>chi2 & \multicolumn{2}{|c|}{0.0008} & \multicolumn{2}{|c|}{0.1424} & \multicolumn{2}{|c|}{0.1579} & \multicolumn{2}{|c|}{0.001} & & & \multicolumn{2}{|c|}{0.0933} \\
\hline
\end{tabular}

Notes: ${ }^{* * *} p<0.01,{ }^{* *} p<0.05,{ }^{*} p<0.1$

In Table 6, models (9-12) and models (13-18) reflect the influence mechanism of the specific export Types, machinery and chemical, in countries with different economic levels. Models (9 and 10) show that in developed countries human capital especially RD positively affects the export of machinery products in both models, while EDU has a positive effect in the fixed-effect model but not in the random-effect model. It is worth mentioning that FDI still does not work in developed countries. In contrast, models (15 and 16) show a very different result on the machinery export in developing countries. FDI is still an important determinant in developing countries, and it has a significant positive effect, meanwhile in human capital variables only RD works on machinery exports. Education, EDU, still has a huge gap on actual manufacturing in developing countries. In the future, developing countries should also focus on improving the quality and spillover effects of higher education, combining education with intelligent manufacturing, so as to enhance the technological driving force of education and promote productivity. For chemical exports, there seems to be no obvious difference. These factors do not have significant effect on chemical exports. Chemical exports may be more affected by other factors such as national policies, organizational systems, etc. This will be an in-depth direction for our future research. The labor pool, POP, has a positive impact on machinery and chemical exports in both developed countries and developing countries in most models. 
Generally speaking, there are significant differences in the intrinsic influence mechanism of export evolution among countries with different economic development worldwide. Human capital including high education and R\&D has the most significant impact on the evolution of core and machinery exports in developed countries. While foreign direct investment and $R \& D$ are important in developing countries, the foreign investment especially holds a decisive position. That means R\&D affects all countries, high education only matters in developed countries, and foreign invest only matters in developing countries.

\section{Conclusions}

During the period 1995-2011, the world experienced major events such as the Asian financial crisis, the accession of developing countries represented by China to the WTO, and the global financial crisis, and then the global economic system tends to stabilize gradually. Many scholars believe that this stage is important to study global trade economy, which can not only help to depict the trade situation and economic driving mechanism of different economies in the global product space network during this period but also can also provide references for improving economic resilience and proposing targeted economic strategic measures for economies of different development levels today.

Based on the product space theory, our study uses the global customs data from 1995 to 2011 to visualize the dynamic product space network, and we have tried to reveal countries' exports status and evolution mechanisms in the dynamic product space networks. It is found that the dynamic product space constructed presents an obvious "core-periphery" heterogeneous structure, and it presented clear clusters in which labor-intensive clusters are located on the periphery, and technology-intensive and capital-intensive clusters are more likely to appear in the core area.

We construct a new indicator "Core" to quantitatively measure countries" export locations in the product space, exploring the impact of a country's specific export model on its economic development. The empirical research found that there were spatial distribution differences on a country's export location and specific export types, i.e., machinery and chemical products, and they had significant impacts on its own economic development. The countries with the highest core are mainly distributed in developed countries, and the developing countries have never been at the forefront of core. Countries with the most machinery and chemical exports belong to developed countries. The more the country's export products are located in the core, the more machinery and chemical products are exported, and the more productive the country will be.

Generally speaking, the production factors such as labor force, human capital, and foreign investment have impacts on a country's evolution of export location and specific export types in global product space, but there are obvious differences among countries with different economic development. For all countries, R\&D investment can always affect export core and specific export types regardless of the countries' economic. While high education only affects export core and machinery exports in developed countries, and FDI is extremely important for the core, machinery, and chemical exports in developing countries. This result shows that high education and R\&D investment in developed countries have effectively promoted technological progress, while the level of education in developing countries is not as good as that of developed countries. At the present stage, developing countries are not able to release strong knowledge spillover effects, and they rely more on the introduction of foreign investment to bring new technology.

In the context of the backflow of the global manufacturing industry and the rise of trade protectionism, developing countries cannot rely solely on the power of foreign investment and need to think about the strategic policies of sustainable development in order to avoid falling into "the trap of middle-income". They should increase R\&D capability, improve the quality of high education to encourage domestic independent innovation, and enter the core area of global product space steadily and quickly. Based on these findings, we will explore the different paths of industry entry and exit in various countries worldwide 
in the future studies and propose specific policies for regional industrial development at the macro-government and micro-enterprise scale.

Author Contributions: X.L. conceived and designed the research; S.L. conducted this research, analyzed the data, and wrote the manuscript; X.H. improved the regression models; H.C. and W.L. revised and reformatted the overall paper. All authors have read and agreed to the published version of the manuscript.

Funding: This research was funded by National Natural Science Foundation of China, grant number nos: 41801163, 41971157.

Institutional Review Board Statement: Not applicable.

Informed Consent Statement: Not applicable.

Data Availability Statement: All datas are available which can be find the source in the "2.1 Data Source". No new data were created or analyzed in this study. Data sharing is not applicable to this article.

Acknowledgments: The authors are thankful to all the anonymous reviewers for their helpful comments. They also appreciate Yang Hao in Lingnan College, Sun Yat-sen University of China.

Conflicts of Interest: The authors declare no conflict of interest.

\section{References}

1. Heckscher, E.F.; Ohlin, B.G. Heckscher-Ohlin Trade Theory; Flam, H., Flanders, M., Eds.; MIT Press: Cambridge, MA, USA, 1991.

2. Ferrarini, B.; Scaramozzino, P. Production complexity, adaptability and economic growth. Struct. Chang. Econ. Dyn. 2016, 37, 52-61. [CrossRef]

3. Frenken, K.; Boschma, R.A. A theoretical framework for evolutionary economic geography: Industrial dynamics and urban growth as a branching process. J. Econ. Geogr. 2007, 7, 635-649. [CrossRef]

4. Isaksen, A. Industrial development in thin regions: Trapped in path extension? J. Econ. Geogr. 2015, 15, 585-600. [CrossRef]

5. Yang, C. Restructuring the export-oriented industrialization in the Pearl River Delta, China: Institutional evolution and emerging tension. Appl. Geogr. 2012, 32, 143-157. [CrossRef]

6. Maskell, P.; Malmberg, A. Myopia, knowledge development and cluster evolution. J. Econ. Geogr. 2007, 7, 603-618. [CrossRef]

7. Neffke, F.M.; Henning, M.; Boschma, R. The impact of aging and technological relatedness on agglomeration externalities: A survival analysis. J. Econ. Geogr. 2012, 12, 485-517. [CrossRef]

8. Essletzbichler, J. Relatedness, Industrial Branching and Technological Cohesion in US Metropolitan Areas. Reg. Stud. 2013, 49, 752-766. [CrossRef]

9. Bahar, D.; Rosenow, S.; Stein, E.; Wagner, R. Export take-offs and acceleration: Unpacking cross-sector linkages in the evolution of comparative advantage. World Dev. 2019, 117, 48-60. [CrossRef]

10. Boschma, R. Proximity and Innovation: A Critical Assessment. Reg. Stud. 2005, 39, 61-74. [CrossRef]

11. Henning, M.; Stam, E.; Wenting, R. Path Dependence Research in Regional Economic Development: Cacophony or Knowledge Accumulation? Reg. Stud. 2013, 47, 1348-1362. [CrossRef]

12. Colombelli, A.; Krafft, J.; Quatraro, F. The emergence of new technology-based sectors in European regions: A proximi-ty-based analysis of nanotechnology. Res. Policy 2014, 43, 1681-1696. [CrossRef]

13. Losurdo, F.; Marra, A.; Cassetta, E.; Monarca, U.; Dileo, I.; Carlei, V. Emerging specializations, competences and firms' proximity in digital industries: The case of London. Pap. Reg. Sci. 2018, 98, 737-753. [CrossRef]

14. Humphrey, J.; Schmitz, H. How does insertion in global value chains affect upgrading in industrial clusters? Reg. Stud. 2002, 36, 1017-1027. [CrossRef]

15. Hirschman, A.O. The Strategy of Economic Development; Yale Univeristy Press: New Haven, CT, USA, 1958.

16. Zhou, X.; Pan, Z.; Shahbaz, M.; Song, M. Directed technological progress driven by diversified industrial structural change. Struct. Chang. Econ. Dyn. 2020, 54, 112-129. [CrossRef]

17. Hidalgo, C.A.; Klinger, B.; Barabasi, A.-L.; Hausmann, R. The Product Space Conditions the Development of Nations. Science 2007, 317, 482-487. [CrossRef]

18. Furusawa, T.; Konishi, H. Free Trade Networks. J. Int. Econ. 2007, 72, 310-335. [CrossRef]

19. Zhang, J.; Xue, L.; Zu, L. Farsighted free trade networks. Int. J. Game Theory 2013, 42, 375-398. [CrossRef]

20. Goyal, S.; Joshi, S. Bilateralism and Free Trade. Int. Econ. Rev. 2006, 47, 749-778. [CrossRef]

21. Pandey, M.; Whalley, J. Social Networks and Trade Liberalization. National Bureau of Economic Research, 2004, Working Paper 10769. Available online: http:/ / www.nber.org/papers/w10769 (accessed on 19 February 2021).

22. Chaney, T. The Network Structure of International Trade. National Bureau of Economic Research, 2011, Working Paper 16753. Available online: http://www.nber.org/papers/w16753 (accessed on 19 February 2021).

23. Zhang, J.; Cui, Z.; Zu, L. The evolution of free trade networks. J. Econ. Dyn. Control. 2014, 38, 72-86. [CrossRef] 
24. Zu, L.; Dong, B.; Zhao, X.; Zhang, J. International R\&D Networks. Rev. Int. Econ. 2011, 19, 325-340. [CrossRef]

25. Hausmann, R.; Klinger, B. South Africa's export predicament. Econ. Trans. 2008, 16, 609-637. [CrossRef]

26. Hidalgo, C.A. The Dynamics of Economic Complexity and the Product Space over a 42 Year Period; Working Paper No. 189; Center for International Development at Harvard University: Cambridge, MA, USA, 2009.

27. Ernst, D. Global Production Network and Industrial Upgrading-A Knowledge-Centered Approach; Working Papers; East West Center: Honolulu, HI, USA, 2001.

28. Ter-Wal, A.L.J.; Boschma, R.A. Applying social network analysis in economic geography: Framing some key analytic issues. Ann. Reg. Sci. 2009, 43, 739-756. [CrossRef]

29. Hidalgo, C.A.; Hausmann, R. A network view of economic development. Dev. Altern. 2008, 12, 5-10.

30. Neffke, F.; Henning, M.; Boschma, R. How Do Regions Diversify over Time? Industry Relatedness and the Development of New Growth Paths in Regions. Econ. Geogr. 2011, 87, 237-265. [CrossRef]

31. Boschma, R.A.; Minondo, A.; Navarro, M. The Emergence of New Industries at the Regional Level in Spain: A Proximity Approach Based on Product Relatedness. Econ. Geogr. 2013, 89, 29-51. [CrossRef]

32. Hausmann, R.; Hwang, J.; Rodrik, D. What you export matters. J. Econ. Growth 2007, 12, 1-25. [CrossRef]

33. Hausmann, R.; Hidalgo, C.A.; Bustos, S.; Coscia, M.; Simoes, A.; Yildirim, M.A. The Atlas of Economic Complexity: Mapping Paths to Prosperity; Mit Press: Cambridge, MA, USA, 2014.

34. Mehta, A.; Felipe, J. Education and the journey to the core: Path dependence or leapfrogging? SSRN 2014, 2467895. [CrossRef]

35. Sachs, J.D.; Warner, A.M. Natural resource abundance and economic growth; Working Paper No. 5398; National Bureau of Economic Research: Cambridge, MA, USA, 1995.

36. Szirmai, A. Industrialisation as an engine of growth in developing countries, 1950-2005. Struct. Chang. Econ. Dyn. 2012, 23, 406-420. [CrossRef]

37. Schott, P.K. Across-Product Versus Within-Product Specialization in International Trade. Q. J. Econ. 2004, 119, 647-678. [CrossRef]

38. Felipe, J.; Kumar, U.; Usui, N.; Abdon, A. Why has China succeeded? And why it will continue to do so. Camb. J. Econ. 2012, 37, 791-818. [CrossRef]

39. Boschma, R.A.; Wenting, R. The spatial evolution of the British automobile industry: Does location matter? Ind. Corp. Chang. 2007, 16, 213-238. [CrossRef]

40. Cruz, J.; Riker, D. Product Space Analysis of the Exports of Brazil; Working Paper; US International Trade Commission: Washington, DC, USA, 2012.

41. Dhrifi, A.; Jaziri, R.; Alnahdi, S. Does foreign direct investment and environmental degradation matter for poverty? Evidence from developing countries. Struct. Chang. Econ. Dyn. 2020, 52, 13-21. [CrossRef]

42. Feenstra, R.; Lipsey, R.; Deng, H.; Ma, A.; Mo, H. World trade flows: 1962-2000; Working Paper No. 11040; National Bureau of Economic Research: Cambridge, MA, USA, 2005. [CrossRef]

43. Barro, R.J.; Lee, J.W. A new data set of educational attainment in the world, 1950-2010. J. Dev. Econ. 2013, 104, 184-198. [CrossRef]

44. Li, S.; Li, X.; Lang, W. China's Export Evolution in the Dynamic Global Product Space from 2000 to 2011. Curr. Sci. 2019, 117. [CrossRef]

45. Li, S.; Feng, P.; Song, Y.; Qin, X.; Li, X. Evolution and Mechanism of China's Exports in a Dynamic Product Space Network. Trop. Geogr. 2020, 40, 40-50. [CrossRef]

46. Romer, P.M. Endogenous Technological Change. J. Polit. Econ. 1990, 98, 77-102. [CrossRef]

47. Lall, S. Competitiveness, Technology and Skills; Elgar: Northampton, MA, USA, 2001.

48. Květoň, V.; Horák, P. The effect of public R\&D subsidies on firms' competitiveness: Regional and sectoral specifics in emerging innovation systems. Appl. Geogr. 2018, 94, 119-129. [CrossRef]

49. Han, H.; Yang, Y.; Zhang, R.; Brekhna, B. Factors and Paths of Transformation and Upgradation of Chemical Industry in Shandong, China. Sustainability 2020, 12, 3443. [CrossRef]

50. $\mathrm{Wu}, \mathrm{Y}$. Indigenous R\&D, Technology Imports and Productivity, Evidence from Industries across Regions of China. Econ. Res. J. 2008, 8, 51-64.

51. Chen, J.; Sheng, Y. An Empirical Study on FDI International Knowledge Spillovers and Regional Economic Development in China. Econ. Res. J. 2008, 12, 39-49. [CrossRef]

52. Görg, H.; Greenaway, D. Much ado about nothing? Do domestic firms really benefit from foreign direct investment? World Bank Res. Obs. 2004, 19, 171-197. [CrossRef]

53. Liu, C.; Guo, Q. Technology Spillover Effect in China: The Spatiotemporal Evolution and Its Drivers. Sustainability 2019, 11, 1694. [CrossRef]

54. Boschma, R.; Minondo, A.; Navarro, M. Related variety and regional growth in Spain. Pap. Reg. Sci. 2011, 91, 241-256. [CrossRef]

55. Lang, W.; Pan, M.; Wu, J.; Chen, T.; Li, X. The patterns and driving forces of uneven regional growth in ASEAN countries: A tale of two Thailands' path toward regional coordinated development. Growth Chang. A J. Urban Reg. Policy 2020, 1-20. [CrossRef]

56. Burke, C.; Goldin, C.; Katz, L.F. The Race between Education and Technology. J. Am. Hist. 2009, 96, 246. [CrossRef] 
57. Li, X.; Hui, E.C.; Lang, W.; Zheng, S.; Qin, X. Transition from factor-driven to innovation-driven urbanization in China: A study of manufacturing industry automation in Dongguan City. China Econ. Rev. 2020, 59, 101382. [CrossRef]

58. Dahlman, C.J.; Routti, J.; Ylä-Anttila, P. Finland as a Knowledge Economy: Elements of Success and Lessons Learned; World Bank: Washington, DC, USA, 2006.

59. Lang, W.; Chen, T.; Li, X. A new style of urbanization in China: Transformation of urban rural communities. Habitat Int. 2016, 55, 1-9. [CrossRef] 